\title{
Legislation
}

\section{Acknowledging or erasing intersex experiences? Gender 'diversity' in German law}

\author{
Peter DunNE* \\ Lecturer in Law, Centre for Health, Law, and Society, University of \\ Bristol Law School
}

\begin{abstract}
Introduction
I n November 2018, the German Parliament enacted legislation to affirm the 'diverse' legal gender of persons who experience intersex variance. ${ }^{1}$ For those who fall within the terms of the new law, it is possible to gain formal acknowledgment as neither 'male' nor 'female'. ${ }^{2}$ The German reform is part of a growing global movement - legal, political and advocacybased - to validate identities and experiences of gender beyond the traditional gender binary. ${ }^{3}$ At present, numerous jurisdictions, including Malta, Canada and New Zealand, provide access to gender registration beyond 'man' and 'woman' categories - although entry requirements across the different regimes vary measurably. ${ }^{4}$ In 2018 , the English High Court was asked to decide whether individuals have an entitlement to an ' $\mathrm{X}$ ' passport, which would include gender markers that are neither male nor female, in this jurisdiction. ${ }^{5}$ In 2018 , the government specifically included non-binary recognition as part of its UK-wide consultation on the Gender Recognition Act 2004. ${ }^{6}$ This note explores Germany's attempt to legislate for the 'diverse' identities of persons who experience intersex. While the note

\section{Pd17563@bristol.ac.uk.}

1 Gesetz zur Änderung der in das Geburtenregister einzutragenden Angaben (GeRegÄndG; Bundesgesetzblatt (BGBl.) 2018 I, 2635. See also, Melissa Eddy, 'Not Male or Female, Germans can now Choose "Diverse” New York Times (New York, 14 December 2018) <www.nytimes.com/2018/12/14/world/europe/transgendergermany-diverse.html>.

2 'Germany Introduces Third Gender - Fails Trans People' (Transgender Europe, 18 December 2018) $<$ https://tgeu.org/germany-introduces-third-gender-fails-trans-people>.

3 Jens Thielen, 'Beyond the Binary: Rethinking the Right to Legal Gender Recognition' (2018) 3 European Human Rights Law Review 249, 249, 254; Michael Bochenek and Kyle Knight, 'Establishing a Third Gender Category in Nepal: Process and Prognosis' (2012) 26(1) Emory International Law Review 11, 29-30; Jack Harrison, Jaime Grant and Jody L Herman, 'A Gender not Listed Here: Genderqueers, Gender Rebels, and OtherWise in the National Transgender Discrimination Survey' (2012) 2 LGBTQ Policy Journal at the Harvard Kennedy School 13; Anna James Neuman Wipfler, 'Identity Crisis: The Limitations of Expanding Government Recognition of Gender Identity and the Possibility of Genderless Identity Documents' (2016) 39(2) Harvard Journal of Law and Gender 491.

4 See generally, Zhan Chiam, Sandra Duffy and Matilda González Gil, Trans Legal Mapping Report (ILGA 2017).

5 Mary Welstead, 'To Bi or not to Bi - Gender and Passport X' (2018) 48(Sep) Family Law 1237. The relevant case is: Re Elan-Cane [2018] EWHC 1530 (Admin).

6 'Reform of the Gender Recognition Act 2004' (UK Government Website, 3 July 2018) <www.gov.uk/government/consultations/reform-of-the-gender-recognition-act-2004>.
\end{abstract}


acknowledges the symbolism of extending legal boundaries beyond 'male' and 'female', it highlights two key weaknesses - non-inclusion and misdirected focus - which limit the potential impact of reform - for intersex communities and for those trans-identified ${ }^{7}$ persons whose identities stretch beyond the binary.

\section{Law reform: a 'diverse' gender option}

Under the new law, individuals - who (through a process of medical certification) experience intersex variance and who do not have a male or female identity - can apply for a 'diverse' gender status rather than having to bring themselves within the existing 'man' and 'woman' categories.

The Commissioner for Human Rights of the Council of Europe defines intersex individuals as 'people who cannot be classified according to the medical norms of socalled male and female bodies with regard to their chromosomal, gonadal or anatomical sex'. ${ }^{8}$ There are no definitive statistics for intersex in Europe - with estimates ranging from between one in every 2000 births, up to 1.7 per cent of the population. ${ }^{9}$ Intersex is distinct from issues relating to transgender communities and the question of 'gender identity. ${ }^{10}$ While 'intersex' concerns experiences of body, 'gender identity' relates to internal understandings of gender. 'Transgender' is an increasingly used umbrella term which embraces all persons who identify with a gender (binary or non-binary) which deviates from the status assigned to them at birth. While a person who experiences intersex might also have a transgender identity, this frequently is not the case.

In October 2017, the German Constitutional Court - which, since 1978, has issued numerous landmark opinions on gender and sexual diversity ${ }^{11}$ - ruled that existing domestic rules for birth registration violated the country's constitutional law. ${ }^{12}$ The legal challenge was initiated by a female-assigned individual, who experienced intersex variance and who self-identified as non-binary. In finding that the current system was constitutionally impermissible, the Constitutional Court held that enforced binary gender (for persons in the position of the litigant) violated both the right to personal

7 'Trans' or 'transgender' refers to individuals who do not self-identify with the gender to which they are assigned at birth.

8 Commissioner for Human Rights of the Council of Europe, Human Rights and Intersex People: Issue Paper (Council of Europe 2015) 13.

9 Leonard Sax, 'How Common is Intersex? A Response to Anne Fausto-Sterling' (2002) (39(3) Journal of Sex Research 174; Melanie Blackless et al, 'How Sexually Dimorphic are We? Review and Synthesis' (2000) 12(2) American Journal of Human Biology 151, 161.

10 The 'Introduction' to the Yogyakarta Principles describes 'gender identity' as 'each person's deeply felt internal and individual experience of gender, which may or may not correspond with the sex assigned at birth, including the personal sense of the body . . . and other expressions of gender, including dress, speech and mannerisms.' Yogyakarta Principles, 'Introduction' (Yogyakarta Principles Website, no date) $<$ www.yogyakartaprinciples.org/introduction>.

11 Anatol Dutta, 'The Legal Status of Transgender and Transsexual Persons in Germany' in Jens M Scherpe (ed), The Legal Status of Transgender and Transsexual Persons (Intersentia 2015) 207-22. Among these various judgments, the German Constitutional Court has struck down the requirement that individuals divorce before obtaining legal gender recognition (Federal Constitutional Court of Germany, 1 BvL 10/05 (23 July 2008)). This is a more progressive approach than that adopted by the European Court of Human Rights (Hamalainen $v$ Finland [2015] 1 FCR 379). The German Constitutional Court also struck down sterilisation requirements prior to the European Court of Human Rights (AP, Garcon and Nicot v France App Nos 79885/12, 52471/13 and 52596/13 (ECtHR, 6 April 2017).

12 Federal Constitutional Court of Germany, 1 BvR 2019/16 (10 October 2017). 
development and guarantees of equality based on sex. ${ }^{13}$ The German government was offered two remedial options: (a) to introduce a 'third' gender option; or (b) to remove the requirement to register legal gender altogether. ${ }^{14}$

As one of the first judicial statements in favour of non-binary gender options, the Constitutional Court judgment stands as an important judicial affirmation of gender diversity. Grounded in substantive constitutional protections, rather than mere advocacy - the decision establishes a coherent rights-based framework for gender recognition outside male and female categorisation.

However, a complicating factor in the opinion is the extent to which the Constitutional Court focused on intersex. Following the judgment, questions arose as to what obligation the decision placed upon the German government. ${ }^{15}$ On the one hand, the judges spoke in general terms about respect for identities beyond male and female. This suggested a possibly broad scope of application - extending to all non-binary persons, irrespective of their experience of body. However, on the other hand, the facts of the constitutional challenge were limited to a specific litigant, who did exhibit nonstandard sex characteristics. Furthermore, the Constitutional Court made frequent reference to those characteristics when explaining its conclusions. There was, thus, an apprehension that the German government would interpret the opinion in a conservative manner - tying third gender rights to experiences of body.

In August 2018, when the German government announced its official response to the judgment, these fears were realised. ${ }^{16}$ The government rejected the possibility of abolishing gender registration, favouring an alternative identity status. Such additional gender classification, however, would be restricted only to those persons who experience intersex variance. These proposals have now been enshrined through the new legislation, as affirmed by Germany's Parliament. ${ }^{17}$ The new law creates an option (not a requirement) for individuals with non-typical sex characteristics to apply for a 'diverse' gender marker. Such marker becomes an official gender designation, and it can be reproduced on all official documentation (e.g. passport, driving licence etc.). In order to obtain 'diverse' gender recognition, an individual must forward an application, along with medical certification relating to intersex variance. Without such certification, applicants are excluded from the alternative gender option.

13 For a substantive analysis of the German Constitutional Court's judgment, see Peter Dunne and Jule Mulder, 'Beyond the Binary: Towards a Third-Sex Category in Germany' (2018) 19(3) German Law Journal 627.

14 Ibid 629-31.

15 Ibid 631.

16 The Draft Bill and Report of the Expert Meeting (both in German) can be found at: $<$ www.bundestag.de/presse/hib/-/580562>

<http://dip21.bundestag.de/dip21/btd/19/046/1904669.pdf>; Grietje Baars offers commentary on the Draft Bill: see Grietje Baars, 'New German Intersex Law: Third Gender but not as We Want It' (Critical Legal Thinking, 24 August 2018) <criticallegalthinking.com/2018/08/24/new-german-intersex-law-third-genderbut-not-as-we-want-it>. See also: 'German Cabinet Approves Third Gender Identity' (DW, 15 August 2018) $<$ www.dw.com/en/german-cabinet-approves-third-gender-identity/a-45090243>.

17 Gesetz zur Änderung der in das Geburtenregister einzutragenden Angaben (GeRegÄndG; Bundesgesetzblatt (BGBl.) 2018 I, 2635. 


\section{Critiquing 'diverse' gender: exclusion and misdirection}

In the comparably short time since its enactment, Germany's 'diverse' gender option has attracted considerable international attention. ${ }^{18}$ Building upon previous attempts by the German legislature to affirm non-binary gender, ${ }^{19}$ the reforms are an important step towards acknowledging diverse, non-standard experiences of identity. Despite the limitations of the law, explored in greater detail below, there is symbolism in acknowledging the possibility of lives which deviate from expected male-female norms. As social science research - across Europe and beyond - reveals, a growing number of individuals self-identify outside the binary, ${ }^{20}$ and these people struggle where domestic legal frameworks marginalise or ignore their experiences. ${ }^{21}$ To the extent that the new law (however imperfectly) embraces a broader vision of gender, this is something which can be (and is) rightly celebrated. ${ }^{22}$ Furthermore, for intersex individuals (including the appellant), whose bodies and lives have been hidden through legal and medical regulation, there may be significance in laws which expressly acknowledge their existence and rights. ${ }^{23}$ Although, as noted below, there is a risk that the reforms mischaracterise and misdirect intersex preferences, there is some positivity in the German legislature taking a stance to acknowledge the concerns of intersex voices.

Despite these positive symbolic elements, however, the new law gives rise to numerous concerns. While some of the critiques (unsurprisingly) come from opponents of lesbian, gay, bisexual and transgender (LGBT) rights in Germany's Parliament, ${ }^{24}$ stronger dissent is evident among domestic and international advocates. ${ }^{25}$ In broad terms, their dissatisfaction with the 'diverse' gender law arises from two claims, that: (a) the reforms misunderstand non-binary identities, excluding a majority of individuals who are neither male nor female; and (b) Parliament's response misdirects intersex concerns, ignoring legitimate complaints regarding bodily integrity. In the remaining sections, this note explores each of these critiques in turn - identifying some key deficiencies which limit the impact of the new law.

18 Colin Drury, 'Germany Approves Third Gender “Intersex" Option for Official Documents' The Independent (London, 15 December 2018) <www.independent.co.uk/news/world/europe/germany-third-gender-identiyofficial-records-diverse-binary-intersex-a8684646.html>; Melissa Eddy, 'Not Male or Female, Germans Can now Choose "Diverse", New York Times (New York, 14 December 2018) <www.nytimes.com/2018/12/14/world/europe/transgender-germany-diverse.html>.

19 Robert Hupf, 'Allyship to the Intersex Community on Cosmetic, Non-Consensual Genital Normalizing Surgery' (2015) 22(1) William and Mary Journal of Women and the Law 73, 96; Adam Herpolsheimer, 'A Third Option: Identity Documents, Gender Non-Conformity, and the Law' (2017) 39(1) Women's Rights Law Reporter 46, 64.

20 See e.g. Christina Richards et al, 'Non-binary or Genderqueer Genders’ (2016) 28(1) International Review of Psychiatry 95.

21 See generally, Genny Beemyn and Susan Rankin, The Lives of Transgender People (Columbia University Press 2011) 26. For information on non-binary experiences in the UK, see Vic Valentine, Non-Binary People's Experiences in the UK (Scottish Trans Alliance 2016).

22 Vade offers an interesting perspective on the merits of increasing legal gender diversity: Dylan Vade, 'Expanding Gender and Expanding the Law: Toward a Social and Legal Conceptualization of Gender that is more Inclusive of 'Transgender People' (2005) 11(2) Michigan Journal of Gender and Law 253.

23 See, generally, Alison Reddick, 'What Happened at Hopkins: The Creation of the Intersex Management Protocols' (2005) 12(1) Cardozo Journal of Law and Gender 289; Fundamental Rights Agency of the European Union, The Fundamental Rights Situation of Intersex People (FRA EU 2015) <file:///C:/Users/peter/Downloads/fra-2015-focus-04-intersex.pdf>.

24 "Gender Adds "Diverse" as a Gender to Birth Register" (DW, 14 December 2018) <www.dw.com/en/germany-adds-diverse-as-a-gender-to-birth-register/a-46737328>.

25 'Germany Introduces Third Gender - Fails Trans People' (Transgender Europe, 18 December 2018) $<$ https://tgeu.org/germany-introduces-third-gender-fails-trans-people>. 


\section{EXCLUDING NON-BINARY IDENTITIES}

An important shortcoming in the 'diverse' gender option is the extent to which it excludes large numbers of individuals who self-identity outside 'man' and 'woman' classifications. In responding to the Constitutional Court judgment, the German government has limited the new rules to persons who experience intersex variance. This means that - although people who have both ambiguous sex characteristics and an ambiguous gender identity may apply for a 'diverse' gender status - all other individuals are excluded. In particular, transgender populations who, although they do not experience a male or female gender, have expected body characteristics, cannot seek relief under the new reforms. ${ }^{26}$

In legal terms, restricting the 'diverse' gender category to intersex communities contradicts (if not the letter) at least the spirt of the 2017 judgment. While, in that case, the Constitutional Court was immediately faced with an intersex litigant, the broader arguments about respect for personal gender and the tangible harms of gender invisibility were equally relevant to non-binary persons. ${ }^{27}$ To the extent that involuntary categorisation as male or female creates impermissible harm for non-binary persons who experience intersex, the same is true for non-binary persons with expected sex characteristics. $^{28}$ Leaving this latter group out of the reform potentially reproduces unconstitutionality and will likely encourage additional litigation. ${ }^{29}$

In practical terms, limiting the new gender status to intersex populations reduces any actual impact that the diverse gender option may have. If a majority of persons who selfidentify outside the binary have typical sex characteristics, those individuals will not be accessing a regime which requires evidence of intersex variance. ${ }^{30}$ Thus, the new law expressly excludes the main constituency to whom its protections should apply.

At the same time, the law does apply to a population, most of whose members have no desire for the 'protections' which the reform offers. ${ }^{31}$ A significant proportion of intersex individuals self-identify within the binary and many persons are sceptical of laws which tie (even implicitly) experiences of intersex to an alternative, 'third' gender classification. ${ }^{32}$ Both the Third and Fourth International Intersex Fora have made explicit recommendations to raise intersex youth within the gender binary (while maintaining a flexibility to transition if required). ${ }^{33}$ Thus, the German law achieves a unique distinction of embracing a group of people who view its introduction with suspicion, while simultaneously excluding those who experience their omission as a deep social injury.

\section{MISDIRECTING INTERSEX CONCERNS}

The new reform is also criticised for concentrating on questions of legal identity despite the fact that - for many intersex persons - their primary concern is the involuntary medicalisation of young intersex bodies.

26 Ibid.

27 Dunne and Mulder (n 13) 633-4.

28 Theodore Bennett, “No Man's Land”: Non-Binary Sex Identification in Australian Law and Policy (2014) 37(3) University of New South Wales Law Journal 847, 850-1.

29 'Germany Introduces Third Gender' (n 25).

30 Ibid.

31 Fae Garland and Mitchell Travis, 'Legislating Intersex Equality: Building the Resilience of Intersex People through Law’ (2018) 38 Legal Studies 587-606, 596-7.

32 Commissioner for Human Rights of the Council of Europe (n 8)

33 See e.g. 'Third International Intersex Forum' (ILGA-Europe, December 2013) <www.ilga-europe.org/whatwe-do/our-advocacy-work/trans-and-intersex/intersex/events/3rd-international-intersex-forum>. 
In Germany, as in many jurisdictions across Europe, there remains concern that medical professionals continue to perform non-therapeutic 'normalising' surgeries on intersex infants. ${ }^{34}$ These procedures are intended to 'correct' sex characteristics which deviate from aesthetic expectations for male or female bodies. ${ }^{35}$ In 2011, the UN Committee against Torture specifically recommended that Germany halt physical interventions, which have no health benefit for young persons who experience intersex. ${ }^{36}$ Indeed, in many respects, German civil society discussions regarding intersex have, for at least a decade, focused on questions of body rather than alternative legal identities. Intersex normalising surgeries raise significant concerns for physical integrity rights, and they have historically been performed in circumstances of secrecy, prioritising medical or parental biases over informed consent. ${ }^{37}$ Given the long-term impact of such treatments, including requirements for multiple interventions and possible loss of sexual sensation, ${ }^{38}$ there are increasing calls within Germany to limit non-therapeutic procedures on intersex bodies.

The new reforms - although acknowledging the existence of intersex lives outside the binary - do nothing to proscribe the involuntary medicalisation of intersex youth. A person who experiences non-standard sex characteristics can apply for a 'diverse' gender option. There is no guarantee, however, that such individual will be protected from external decisions to physically amend their healthy body as an infant. For many intersex individuals, such protections are significantly more important than affirming alternative gender categories.

A similar critique was offered against an earlier German law in 2013. That original law, which was challenged as part of the 2017 litigation, created a non-specified gender category in which intersex children could be placed if, at the point of birth, it was not possible to assign a definitive legal sex classification. ${ }^{39}$ The rationale for the 2013 reform was that, by removing a requirement to immediately gender intersex infants, parents and doctors would be encouraged to refrain from undertaking unnecessary surgical interventions. However, there is suggestion that, rather than reducing 'normalising' procedures, the 2013 law has increased such treatments - with parents anxious to avoid

34 Amnesty International, First, Do No Harm: Ensuring the Rights of Children with Variations of Sex Characteristics in Denmark and Germany (Amnesty International 2017); OII-Europe, 'New Draft Bill in Germany Fails to Protect Intersex People' (OII-Europe, 20 August 2018) https://oiieurope.org/new-draft-bill-in-germany-fails-toprotect-intersex-people>. See also Jens Scherpe, Tobias Helms and Anatol Dutta, The Legal Status of Intersex Persons (Cambridge University Press 2018) where there are contributions on numerous European jurisdictions, such as France, Netherlands and Sweden. For a broader, pan-European perspective, see: Commissioner for Human Rights of the Council of Europe (n 8)

35 For a general overview of medico-legal controversies surrounding genital normalising surgeries, see Melanie Newbould, 'When Parents Choose Gender: Intersex, Children and the Law' (2017) 24(4) Medical Law Review 474. This article deals with many of the issues which have direct relevance within the current German debate.

36 UN Committee against Torture, 'Concluding Observations on the Fifth Periodic Report of Germany' (12 December 2011) UN Doc No CAT/C/DEU/CO/5, [20].

37 Alison Davidson, 'Surgery for Intersex Children' (2011) 26 Wisconsin Journal on Law, Gender and Society 1, 15-16; Anne Tamar-Mattis, 'Exceptions to the Rule: Curing the Law's Failure to Protect Intersex Infants' (2006) 21 Berkeley Journal of Gender, Law and Justice 59, 59. Newbould notes how, while we may assume that parents will act for the welfare of their child, this might not always be objectively the case where parents are confronted with sexual diversity: Newbould (n 35) 478.

38 Kishka-Kamari Ford, 'First, Do No Harm - The Fiction of Legal Parental Consent to Genital-normalizing Surgery of Intersexed Infants' (2001) 19(2) Yale Law and Policy Review 469, 485; Erin Lloyd, 'Intersex Education, Advocacy and the Law: The Struggle for Recognition and Protection' (2005) 11(2) Cardozo Women's Law Journal 283, 284.

39 Law on Civil Status (Personenstandsgesetz), s 22(3). 
the stigma of the non-specified gender category. ${ }^{40}$ As in 2013, critics of the new law argue that, if policy-makers aim to reduce the rate of non-therapeutic surgeries, legal prohibition is the most coherent, effective method.

\section{Conclusion}

The new 'diverse' gender option in Germany represents a symbolic milestone in European gender politics. Acknowledging the possibility of lives outside 'man' and 'woman', the reform is a significant affirmation for non-binary experiences. Yet, by tying gender diversity to intersex, the German Parliament has limited both the practical and symbolic impact of the new legislation. The 'diverse' gender category excludes transidentified non-binary communities and obscures broader intersex advocacy demands most notably the eradication of involuntary normalising surgeries. Germany's intervention is an important step forward - but it must be reinforced (in Germany and beyond) by laws which respond to the actual lived-experience of gender (inside and outside the binary) across Europe.

40 Garland and Travis (n 31) 600-01 speak to emerging and anecdotal evidence in this regard. Of course, given the invisibility of intersex lives - particularly within the medical sphere - it is difficult to identify definitive evidence that the 2013 law has precipitated a rise in surgical procedures on young intersex bodies. 
